\title{
KOMUNIKASI SIMBOLIK DALAM UPACARA PERNIKAHAN MANJAPUIK MARAPULAI DI NAGARI PANINJAUAN SUMATERA BARAT
}

\author{
Lusiana Andriani Lubis dan Zikra Khasiah \\ Program Studi Magister Ilmu Komunikasi FISIP Universitas Sumatera Utara, \\ Jln. Dr.Sofyan No.1 Kampus USU Medan, Telp: 08126469794, \\ Email:Lus1ana_andr1an1@yahoo.com
}

\begin{abstract}
The goal is this research to see the symbols of figurative language and to analyze the meaning and significance of symbols figurative language in the wedding ceremony manjapuik marapulai in Paninjauan village, Tanah Datar district, West Sumatera. The research employs qualitative study using content analysis (symbolic) and analysis of Roland Barthes semiology be the significance of the two stages (two orders of signification) denotation and connotation, as well as mythical as the development of connotation. The study found that symbols contained in panitahan at a ceremony manjapuik marapulai conform with values and philosophy of Minang adopted by local community. Symbols are included in the 15 sentences that comes from nature, conform with the philosophy of alam takambang manjadi guru as the sentence Tantangan kato ayam lai barinduak, which is a lesson from nature that chickens need of parent in guiding his life as well as humans who need parents in shows about customs. One sentence that comes to the religious teachings of Islam: Adat badiri di nan patuik, syarak mamakai pado dalil, limbago duduak bajauahan, tarapak sambah ka tangah, taunjuak ka muko rapek, the doctrine greeting to people who attend an event. Then 11 sentences that comes to tradition, philosophy, ideology and ethics of society as a sentence Pusako duduak di nan rapek, kato surang dibulati, kato basamo dipaiyo, direnjeang kato jo mupakat which is the ideology of the people in Paninjauan village that is discussion.
\end{abstract}

Keywords: symbolic communication, marapulai Manjapuik, semiotic analysis.

\begin{abstract}
Abstrak
Penelitian ini ingin melihat simbol-simbol bahasa kiasan dan menganalisis arti dan makna dari simbol bahasa kiasan dalam upacara pernikahan manjapuik marapulai di Nagari Paninjauan, Kabupaten Tanah Datar Sumatera Barat. Metode yang digunakan dalam penelitian ini adalah metode penelitian kualitatif dengan menggunakan analisis isi (simbolik) dan analisis semiologi Roland Barthes berupa signifikasi dua tahap (two order of signification) yaitu denotasi dan konotasi, serta mitos sebagai pengembangan dari konotasi. Hasil penelitian menemukan bahwa simbol yang terdapat dalam panitahan pada upacara manjapuik marapulai sesuai dengan nilai-nilai dan falsafah Minang yang dianut oleh masyarakat setempat. Simbol tersebut terdapat dalam 15 kalimat yang bersumber dari alam, sesuai dengan falsafah alam takambang manjadi guru seperti kalimat Tantangan kato ayam lai barinduak, yang merupakan pelajaran dari alam yaitu ayam yang membutuhkan induk dalam menuntun kehidupannya begitu juga dengan manusia yang membutuhkan orang tua dalam menunjukkan tentang adat istiadat. Satu kalimat yang bersumber kepada ajaran agama Islam yaitu Adat badiri di nan patuik, syarak mamakai pado dalil, limbago duduak bajauahan, tarapak sambah ka tangah, taunjuak ka muko rapek, yaitu ajaran untuk mengucapkan salam kepada orang yang hadir dalam suatu acara. Kemudian 11 kalimat yang bersumber kepada tradisi, falsafah, ideologi dan etika masyarakat seperti kalimat Pusako duduak di nan rapek, kato surang dibulati, kato basamo dipaiyo, direnjeang kato jo mupakat yang merupakan ideologi masyarakat di Nagari Paninjauan yaitu Musyawarah.
\end{abstract}

Kata kunci: komunikasi simbolik, manjapuik marapulai, analisis semoitik.

\section{Pendahuluan}

Komunikasi merupakan dasar bagi manusia dalam memulai aktivitasnya, demikian juga dengan hubungan antarsesama. Manusia sebagai makhluk sosial tidak pernah lepas dari interaksi sosial sehingga komunikasi bukan hanya sekedar kepentingan saja, akan tetapi sudah menjadi kebutuhan bagi setiap manusia. Komunikasi yang dilakukan 
baik secara lisan (verbal) maupun dengan isyarat (non verbal), seperti saat kita mengerjakan tugas baik itu sekolah, kuliah, dan tugas lainnya, kita akan meminta bantuan teman agar bisa menyelesaikan tugas dengan baik.

Dalam konteksnya, komunikasi terdiri dari komunikasi di depan umum (komunikasi publik), bicara dengan teman (komunikasi antarpribadi) dan sebagainya. Masyarakat Minangkabau juga memiliki berbagai jenis komunikasi. Ada empat hal yang merupakan dasar bagi masyarakat Minang dalam berkomunikasi terhadap semua orang, yang dikenal dengan istilah kato nan ampek atau jalan nan ampek (kata yang empat/jalan yang empat) yaitu "kato mandaki" yang artinya perkataan yang digunakan untuk berbicara dengan orang yang lebih tua dari kita yaitu dengan bahasa yang sopan santun dan menghormatinya. "Kato manurun" untuk berbicara kepada orang yang lebih muda/kecil dari kita dengan bahasa kasih sayang. "kato mandata" untuk berbicara dengan teman sebaya dengan bahasa yang menghargainya dan "kato malereng" yang merupakan kata sindiran dan kata kiasan yang digunakan kepada seluruh elemen masyarakat (Sayuti, 2005 : 17).

Kata kiasan menurut kamus besar bahasa Indonesia adalah pertimbangan tentang suatu hal dengan perbandingan atau persamaan dengan hal yang lain, perumpamaan; ibarat, arti kata yang bukan sebenarnya, lambang, sindiran, pelajaran (dari suatu cerita dan sebagainya) (http://kbbi.web.id/ kias). Sumber lain menyebut kata kiasan sebagai kata-kata yang berbungabunga, bukan dalam arti kata yang sebenarnya; kata kiasan dipakai untuk memberi rasa keindahan dan penekanan pada pentingnya hal yang disampaikan, misalnya : "cita-citanya setinggi langit," dan "wajahnya bagaikan rembulan" (Ensiklopedia). Jadi, bahasa kiasan adalah bahasa perumpamaan yang digunakan untuk memberi rasa keindahan bagi pendengarnya. Orang Minang, terutama pada Nagari yang diteliti ini sering menggunakan bahasa kiasan dalam acara formil maupun dalam pembicaraan sehari-hari sesuai dengan pepatah Minang yang menyatakan : "manusia tahan kias, kerbau tahan pukul" yang artinya manusia dengan bahasa kiasan saja sudah mengerti maksud dan tujuan dari si pembicara (komunikator), dan menunjukan bahwa kiasan merupakan bahasa yang disukai dan menjadi salah satu keunikan dan ciri khas masyarakat Minangkabau (Oktavianus, 2012 : 1).

Setiap pertemuan adat di alam Minangkabau selalu melaksanakan Alur Panitahan, yakni pidato adat yang diucapkan sewaktu duduk bersama untuk musyawarah menyetujui suatu maksud (Jamin, 2006 : 3). Dalam panitahan (percakapan adat) tersebut, terdapat bahasa kiasan yang digunakan oleh mamak baik dari pihak perempuan maupun pihak laki-laki untuk menyampaikan maksud dan tujuannya dalam hal meminang, bertukar tanda, menjemput marapulai (laki-laki yang dilamar), dan juga mengantarkan marapulai ke rumah anak daro (perempuan yang melamar).

Penelitian ini mengkaji lebih dalam bahasa kiasan dalam salah satu proses upacara pernikahan di Nagari Paninjauan, yaitu Manjapuik marapulai. Manjapuik marapulai adalah proses menjemput pengantin pria yang akan tinggal bersama istri di rumah keluarga istri. Acara ini merupakan proses akhir dalam upacara pernikahan di Nagari Paninjauan. Hal ini terjadi karena sistem kekerabatan Minangkabau yang menganut Matrilineal. Peneliti akan mengungkap makna dari bahasa kiasan dalam acara manjapuik marapulai dan alasan historis yang terdapat dalam 
penggunaan bahasa tersebut. Hal inilah yang menjadi fokus masalah dalam penelitian mengenai bahasa kiasan dalam acara manjapuik marapulai tersebut.

Semua makna budaya diciptakan menggunakan simbol-simbol. Simbol mengacu kepada pendapat Spradley (1997) adalah objek atau peristiwa apapun yang menunjuk kepada sesuatu. Semua simbol melibatkan tiga unsur yaitu (1) simbol itu sendiri, (2) satu rujukan atau lebih, (3) hubungan antara simbol dengan rujukan. Semua itu merupakan dasar bagi keseluruhan makna simbolik (dalam Tinarbuko, 2010:19).

Susanne K. Langer (dalam Mulyana, 2008 : 92) mengemukakan bahwa salah satu kebutuhan pokok manusia adalah kebutuhan simbolisasi atau penggunaan lambang, dan inilah yang menjadi pembeda manusia dengan makhluk hidup lainnya. Lambang atau simbol adalah sesuatu yang digunakan untuk menunjuk sesuatu lainnya berdasarkan kesepakatan sekelompok orang. Lambang meliputi kata-kata (pesan verbal), perilaku non verbal, dan objek yang maknanya disepakati bersama. Seperti sirih dan pinang yang merupakan suatu objek yang maknanya begitu penting dalam upacara adat di Minangkabau. Cincin yang merupakan lambang bagi sepasang kekasih dalam menjalin hubungan ke tahap yang lebih serius, dan sebagainya. Lambang adalah salah satu kategori tanda (Mulyana, 2008 : 92). Littlejohn (dalam Sobur, 2004 : 15) berpendapat bahwa tanda-tanda merupakan basis dari seluruh komunikasi. Semiotika adalah suatu ilmu atau metode analisis untuk mengkaji tanda. Semiotika atau dalam istilah Barthes semiologi, pada dasarnya hendak mempelajari bagaimana kemanusiaan (humanity) memaknai halhal (things) (Sobur, 2004 : 15).

Dasar penelitian ini menggunakan semiology merujuk kepada gagasan
Ferdinand de Saussure yang menjadi acuan bagi Roland Barthes dalam mengembangkan ilmu semiotika. Roland Barthes (1915-1980) merupakan salah satu ahli semiotika pascastrukturalis yang mengembangkan Semiologi Ferdinand de Saussure dengan analisis strukturalnya (Sobur, 2004 : 63). Barthes mengemukakan konsep tentang konotasi dan denotasi sebagai kunci dari analisisnya. Lebih tepatnya konsep itu disebut signifikasi dua tahap (two order of signification). Barthes menjelaskan bahwa konsep ini diawali dengan hubungan antara signifier (ekspresi/ penanda) dan signified (content/ petanda) dalam sebuah tanda terhadap realitas eksternal yang merupakan signifikasi tahap pertama. Hal ini disebut Barthes sebagai denotasi yaitu makna paling nyata dari tanda. Signifikasi tahap kedua yang disebut konotasi oleh Barthes, menggambarkan interaksi yang terjadi ketika tanda bertemu dengan perasaan atau emosi dari pembaca serta nilai-nilai dari kebudayaannya. Dengan kata lain denotasi adalah apa yang digambarkan tanda terhadap sebuah objek, sedangkan makna konotasi adalah bagaimana cara menggambarkannya (Wibowo, 2011 : 17).

Barthes mengembangkan teori konotasi sebagai dasar untuk mengkaji budaya dan membangun teori tentang kebudayaan. Konotasi tentang suatu gejala budaya dapat terbentuk pada suatu komunitas. Dalam kajian tentang kebudayaan, konotasi tersebut dikembangkannya menjadi teori tentang mitos yang berbeda dengan mitos yang dikenal secara umum. Mitos dalam arti khusus ini merupakan perkembangan dari konotasi, yaitu pemaknaan tanda yang bersifat arbitrer (sewenang-wenang) sehingga terbuka untuk berbagai kemungkinan. Mitos dengan arti tersebut dikatakan Barthes sebagai sistem semiologi (Hoed, 2011:66-67). Bicara tentang mitos, 
merupakan suatu wahana dimana suatu ideologi berwujud. Mitos dirangkai menjadi mitologi yang berperan penting dalam kesuatuan-kesatuan budaya. Van Zoest (1991) menegaskan, siapapun bisa menemukan ideologi dalam teks dengan jalan meneliti konotasi-konotasi yang terdapat di dalamnya (Wibowo, 2011 : 18).

Proses upacara pernikahan di Minangkabau secara umum adalah: (1) Mancari minantu yaitu penjajakan untuk mencari calon menantu yang dilakukan secara diam-diam dan biasanya dilakukan oleh bako, yaitu saudara kandung dari ayah calon mempelai. (2) Batimbang tando yaitu pihak laki-laki dan perempuan saling bertukar tanda menurut adat. Biasanya batimbang tando dilaksanakan setelah adanya kesepakatan kedua belah pihak. Tanda tersebut bisa berupa cincin, keris dan sebagainya, sesuai adat yang berlaku di Nagari tersebut. (3) Menikah, hari pernikahan ditentukan pada saat batimbang tando. (4) Baralek, yaitu peresmian pernikahan antara mempelai laki-laki dengan mempelai perempuan yang biasa dikenal dengan Kenduri. Hari kenduri ini juga ditentukan pada saat batimbang tando. Kenduri ini juga berbeda pelaksanaannya disetiap Nagari (Zulkarnaini, 2003 : 51).

Pelaksanaan pernikahan di Minangkabau, khususnya di Nagari Paninjauan memiliki ciri khas yang berbeda dari berbagai suku bangsa yang ada di Indonesia. Seperti pada saat lamaran, pihak perempuan yang datang kepada pihak laki-laki untuk menyampaikan niat melamar tersebut. Kemudian pada saat upacara pernikahan dilangsungkan, dikenal istilah "manjapuik marapulai" yaitu pihak perempuan mendatangi lakilaki untuk dibawa ke rumah perempuan tersebut. Dalam proses menjemput marapulai ini juga ada panitahan atau pasambahan yang dibawakan oleh mamak dari pihak perempuan yang ingin menjemput calon mempelai pria. Pihak laki-laki dalam hal ini diwaliki oleh paman (mamak) yang menyambut pihak perempuan tersebut dan mempersilahkan untuk dibawa kepada calon mempelai wanita.

Manjapuik marapulai merupakan salah satu proses dan acara yang terdapat dalam upacara pernikahan di Minangkabau. Manjapuik marapulai berasal dari bahasa Minang itu sendiri yang artinya adalah menjemput pengantin pria. Acara manjapuik marapulai berlangsung setelah acara baralek (kenduri) di rumah pengantin pria tersebut. Acara ini merupakan proses terakhir dari upacara pernikahan di Nagari Paninjauan. Bahri Rangkayo Mulia (dalam Amir, 2003 : 17) salah seorang tokoh pemuka adat menguraikan adat manjapuik marapulai dalam majalah kebudayaan Minangkabau. Beliau mengungkapkan bahwa marapulai yang bersumando/bermenantu (akan pindah) ke rumah yang bermamak (beradat), maka adalah haknya menurut adat untuk dijemput oleh pihak mamak rumah dari keluarga istrinya.

Pelaksanaan acara manjapuik marapulai, mamak dari pihak perempuan datang beserta urang sumando untuk menjemput marapulai. Urang sumando adalah orang yang berada di lingkungan tempat tinggal istri yang mengiringi mamak dalam acara tersebut, dengan membawa bingkisan adat sebagai penjemput marapulai. Bingkisan adat ini merupakan lambang pesan dan amanat dari keluarga penjemput, yang terdapat dalam rempah-rempah pada bingkisan tersebut. Adapun pesan yang disampaikan oleh keluarga melalui bingkisan adat tersebut bahwa pihak keluarga istri telah menyambut kedatangan urang sumando tersebut dengan hati yang tulus dan suci, dan sebagai wujud penghargaan dari pihak keluarga terhadap urang sumando mereka. 


\section{Metode Penelitian}

Metode yang digunakan dalam penelitian ini adalah metode penelitian kualitatif yang didasarkan pada penafsiran, dengan konsep-konsep yang umumnya tidak memberikan angka numerik, seperti etnometodologi atau jenis wawancara tertentu. Dalam penelitian kualitatif, teknik penelitian dengan menggunakan analisis isi (simbolik) ini ditekankan pada bagaimana peneliti melihat keajegan isi komunikasi secara kualitatif, pada bagaimana peneliti memaknakan isi komunikasi, membaca simbol-simbol, memaknai isi interaksi simbolis yang terjadi dalam komunikasi (Bungin, 2008 : 156).

Objek dalam penelitian ini adalah makna bahasa kiasan yang digunakan dalam upacara pernikahan manjapuik marapulai di Nagari Paninjauan tersebut. Adapun teknik pengumpulan data melalui wawancara Mendalam yang tidak berstruktur dan tidak ada settingan wawancara yang baku. Wawancara dilakukan secara intens untuk mendapat data yang lengkap dan mendalam. Pihak yang diwawancarai dalam penelitian ini yaitu ninik mamak, mamak dan stakeholder yang terkait dalam upacara pernikahan 'manjapuik marapulai' di Minangkabau. Juga observasi dilakukan peneliti dengan melihat langsung upacara pernikahan manjapuik marapulai di Nagari Paninjauan dan merekam semua percakapan yang terjadi dalam acara tersebut. Selain itu dengan studi dokumen yaitu dengan mengumpulkan dan menghimpun data melalui literatur dan sumber bacaan yang mendukung penelitian. 'Bahasa' dianalisis dengan menggunakan teks dan referensi yang jelas sumbernya dan menunjang topik penelitian.

Pada tahapan analisis dimana peneliti ini menelaah bahasa kiasan pada panitahan manjapuik marapulai dengan menganalisis simbol yang terdapat dalam bahasa kiasan. Bahasa kiasan tersebut dianalisis dengan menggunakan perangkat analisis semiologi Roland Barthes dengan signifikasi 2 tahap yaitu tanda denotatif sebagai signifikasi tahap pertama dan tanda konotatif sebagai signifikasi tahap kedua. Mitos juga terdapat dalam unsur semiologi Roland Barthes yang merupakan pengembangan dari tanda konotatif. Mitos merupakan pemaknaan tanda yang bersifat arbitrer (sewenang-wenang) digunakan dalam mengkaji kebudayaan (Hoed, 2011 : 66-67). Mitos dalam semiologi Roland Barthes berbeda dengan mitos dalam arti sebenarnya, namun mengungkapkan nilai-nilai yang terdapat dalam tanda kebudayaan seperti yang dikemukakan Van Zoest (1991). Zoest mengemukakan bahwa siapapun bias menemukan ideologi dalam teks dengan jalan meneliti konotasikonotasi yang terdapat di dalamnya.

\section{Hasil Penelitian dan Pembahasan}

Pada mulanya peneliti melakukan pengamatan secara langsung upacara manjapuik marapulai di Nagari Paninjauan terhadap dua resepsi pernikahan yang berlangsung pada tanggal 25-26 Desember 2014. Pengantin pria merupakan orang Paninjauan asli yang tinggal di jorong Hilie Balai, dan pengantin wanitanya berasal dari jorong Ngalau Kota Padang Panjang. Suku pengantin pria "pisang" dan pengantin wanita adalah "jambak". Pengantin ini berasal dari daerah yang berbeda yang disatukan dalam pernikahan. Observasi selanjutnya dilakukan pada tanggal 27 Desember 2014 di hari pernikahan pengantin yang tinggal di jorong Tabu Baraie. Kedua pengantin berasal dari Nagari dan jorong yang sama yaitu Nagari Paninjauan dan jorong Tabu Baraie, yang membedakannya adalah suku. Suku pengantin wanita adalah "pisang" dan suku laki-laki adalah "sikumbang". 
Selanjutnya peneliti melakukan wawancara mendalam setelah memperoleh data melalui observasi. Orang ahli yang mengetahui seluk beluk adat, sejarah dan asal usulnya dan segala sesuatunya yang berkaitan dengan adat Minangkabau. Informan yang dimintai keterangan dalam penelitian ini tentunya orang yang telah ahli dan mumpuni dalam adat dan upacara pernikahan, yakni orang yang menguasai seluk beluk adat dalam Nagarinya yang dianggap pemuka adat yaitu Pengulu. Pengulu di Nagari Paninjauan ini di panggil dengan sebutan Datuk. Dalam memanggil Datuk ini juga tidak sembarangan, masyarakat di Nagari ini memiliki aturan tersendiri yang sesuai dengan tingkat kekerabatannya. Seperti jika Datuk tersebut itu merupakan paman kita, maka kita hendaknya memanggil Datuk itu dengan sebutan "Mak Datuk" yang artinya Paman yang bergelar Datuk, dan jika beliau merupakan Kakek kita maka kita memanggilnya dengan sebutan "Andung Datuk" yang artinya kakek yang bergelar Datuk.

Peneliti mewawancarai empat informan yang merupakan ninik mamak dan mamak yang sudah berpengalaman dalam membawakan panitahan pada acara manjapuik marapulai sesuai dengan subjek penelitian. Informan tersebut diantaranya Sutan Majo Kayo/Mak Kayo Bancah yang merupakan mamak orang Paninjauan. Banyak pengalaman yang telah dijalani beliau dalam mengikuti upacara pernikahan, mulai dari menjadi urang sumando yang disuruh menjemput marapulai, sampai kepada menjadi mamak pihak laki-laki (tuan rumah) dalam menyempaikan dan menjawab panitahan dari berbagai pemuka adat yang datang dalam upacara pernikahan yang diikutinya. Bahkan Mak Kayo juga sering diminta menjadi mamak pihak laki-laki dalam upacara manjapuik marapulai dari berbagai Nagari untuk menggantikan mamak marapulai tersebut. Kemudian Datuk Lelo Kayo yang merupakan ninik mamak yang berpengalaman dalam panitahan dalam upacara pernikahan, informan ketiga adalah Datuk Basa nan Kuniang, ninik mamak suku lain di Nagari Paninjauan yang menguasai panitahan disetiap upacara adat Minang, dan yang terakhir mak Win (Edwin Budianto) merupakan mamak yang berprestasi dalam membawa panitahan pada acara manjapuik marapulai yaitu ditingkat kabupaten/kotapun sudah ditaklukkannya dengan meraih juara pertama pada lomba panitahan manjapuik marapulai di Padang tahun 2003. Panggung di tingkat kelurahan dan kecamatan juga sudah dikuasainya. Kemampuannya sudah diakui oleh provinsi dalam hal panitahan manjapuik marapulai tersebut.

Sesuai dengan keterangan dari empat informan dan masyarakat sekitar yakni ninik mamak pihak perempuan yang datang kepada pihak laki-laki untuk melakukan lamaran, setelah orang tua dari kedua belah pihak setuju dengan hubungan anak mereka. Acara ini disebut batimbang tando. Para mamak tersebut yang akan berbicara dan memutuskan kapan hari dan bulan baik bagi keduanya untuk melangsungkan pernikahan. Adat ini telah bergeser seiring berjalannya waktu dan perkembangan zaman, dimana dahulunya paman yang mencarikan jodoh buat kemenakannya. Sebelum dikenalkan kepada kemenakannya, paman dan keluarga dari kemenakannya berkumpul untuk membicarakan bakal calon dari kemenakannya. Hasil dari pertemuan tersebut diperoleh dengan menyetujui atau tidaknya orang tua dari kemenakan tersebut terhadap calon yang telah dipilihkan oleh paman tersebut. Jika orang tuanya setuju, maka barulah mereka dipertemukan. Biasanya anak tidak bisa menghindar dari jodoh yang telah dicarikan mamak dan disetujui oleh 
orang tuanya, sehingga anak hanya bisa pasrah dengan pilihan tersebut. Akan tetapi adat mencarikan jodoh sudah mulai hilang, sekarang anak itu sendiri yang mencari dan menemukan jodohnya.

Acara batimbang tando juga menentukan tanggal pernikahan bagi kedua calon mempelai. Setelah menentukan tanggal pelaksanaan pernikahan kedua calon mempelai tersebut, orang tua dan segenap keluarga dari kedua mempelai mulai mempersiapkan untuk acara pernikahan tersebut sesuai dengan adat yang berlaku. Jika acara pernikahan ini tidak dilaksanakan sesuai adat, maka kedua belah pihak keluarga tersebut menanggung malu disebabkan acara tersebut tidak dijalankan secara adat. Orang pertama yang akan disebut oleh orang kampung nantinya adalah mamak dari kedua mempelai tersebut. Image mamak di kampung itu menjadi buruk dan dampaknya orang tidak akan menghargai mamak tersebut, apalagi jika mamak dari kedua mempelai tersebut adalah seorang penghulu di Nagarinya. Orang kampung tidak lagi menghargai dan tidak akan mengikuti kepemimpinan penghulu/datuk tersebut. Itulah yang membuat segenap keluarga yang akan melaksanakan pernikahan benar-benar membantu dengan maksimal, agar acara tersebut berjalan sesuai dengan adat istiadat di Nagari Paninjauan.

Beberapa hari sebelum hari pernikahan berlangsung, diadakan rapat antar-mamak untuk membahas siapa saja yang akan dipanggil dan diundang untuk datang ke acara kenduri tersebut. Perundingan dalam rapat itu menentukan siapa saja yang akan di undang dalam pernikahan tersebut, diutamakan pada seluruh masyarakat di Nagari tempat dilangsungkannya pesta pernikahan. Forum rapat mengutus dua orang untuk mengundang masyarakat sekitar yaitu orang yang belum bergelar atau masih lajang, dan orang yang sudah bergelar yaitu orang yang sudah berkeluarga. Dalam istilah minang yaitu "ketek banamo gadang bagala" yang maksudnya sebelum menikah orang tersebut dipanggil namanya saja, setelah menikah orang tersebut sudah diberi gelar dan masyarakat tidak boleh memanggil nama orangnya, melainkan gelarnya yang menandakan orang tersebut sudah dewasa dan memiliki tanggung jawab, sehingga orang ini diberi penghargaan dengan memberi gelar kepadanya. Orang lajang yang akan memanggil untuk mengundang masyarakat dengan membawa carano berisikan sirih, pinang dan rokok sebagai alat komunikasi basa basi dan pembuka kata bagi masyarakat di Nagari Paninjauan. Orang yang sudah bergelar tersebut yang akan berbincang dengan orang yang diundang pada upacara pernikahan.

Kenduri dilangsungkan setelah tiba tanggalnya. Kenduri dilaksanakan di rumah mempelai wanita. Saat kenduri berlangsung keluarga dari pihak lakilaki atau yang disebut sipangka tadi melakukan salah salah satu rutinitas adat pernikahan yaitu manyilau kandang. Manyilau kandang maksudnya keluarga dari pihak laik-laki bertamu ke rumah perempuan yang menjadi menantunya itu untuk mengetahui bagaimana keadaan rumah yang akan menjadi tempat tinggal baru anaknya tersebut. Kemudian manyilau kandang ini juga bertujuan untuk perkenalan keluarga dan kerabat pihak laki-laki dengan kerabat pihak perempuan, juga bersilaturrahmi karena dengan pernikahan ini berarti anggota keluarga bertambah, sehingga hendaknya saling mengenal satu sama lain. Kenduri kemudian dilaksanakan di kediaman mempelai pria. Malam hari setelah kenduri selesai, barulah dimulai acara manjapuik marapulai.

Manjapuik marapulai merupakan salah satu aktivitas adat dalam upacara 
pernikahan dimana mempelai pria dijemput oleh keluarga pihak perempuan untuk dibawa ke rumahnya dan hidup di lingkungan keluarga istrinya. urang sumando (saudara ipar) yang ada di lingkungankeluarga perempuan ditemani seorang mamak diutus untuk menjemput marapulai, yang akan berkomunikasi dengan petatah petitih/panitahan kepada mamak pihak laki-laki untuk menjemput marapulai secara adat. Urang sumando mengiringi mamak dengan membawa carano berisikan sekapur sirih dan uang jemputan/uang tebusan yang diberikan sebagai ganti kemenakan yang hilang dari rumah orang tuanya. Uang itu tergantung kesepakatan dan tergantung seberapa penting mempelai laki-laki dalam kaumnya ataupun orang tua. Jika mempelai adalah penghulu atau orang tuanya, maka uang jemputan tersebut seharga 1 keping emas saat ini atau kurang lebih sekitar Satu Juta Lima Ratus Ribu Rupiah. Jika orang biasa yang jarang aktif dalam Kerapatan Adat Nagari itu biasanya dimulai dari tiga ratus ribu rupiah, ada yang lima ratus ribu rupiah dan lain-lain sesuai dengan kesepakatan para ninik mamak dan kedua belah pihak. Adat tersebut berlaku longgar dalam arti bahwa adat akan memberi keringanan kepada masyarakat di Nagari Paninjauan untuk tidak melaksanakan suatu hal yang telah di tetapkan adat. sesuai dengan pepatah Minang abih adat dek bakarilaan yang artinya adat tidak dilakukan karena sudah mufakat dan saling berkerelaan.

Acara manjapuik marapulai merupakan proses upacara perikahan yang terakhir namun sangat penting. Disinilah mempelai pria akan mendapatkan pengakuan serta penghargaan sebagai mamak rumah, mamak bagi keponakannya kelak yang keputusannya sangat penting terhadap keponakan tersebut. Wujud penghargaan tersebut yaitu dengan memberi gelar kepada si marapulai.
Gelar tersebut merupakan gelar Minang yang diturunkan dari keluarganya, atau dari keluarga pihak ayahnya tergantung kesepakatan ninik mamak. Jika gelar tersebut sudah dikukuhkan kepada mempelai pria, maka siapapun orangnya tua muda tidak boleh memanggil mempelai dengan nama kecilnya. Marapulai tersebut harus dipanggil dengan gelarnya. Pemberian gelar kepada marapulai dimusyawarahkan oleh ninik mamak melalui pidato adat berupa dialog yang disebut dengan panitahan. Hal ini merupakan salah satu keunikan budaya Minangkabau yang merupakan salah satu kekayaan budaya Bangsa.

Panitahan merupakan pidato adat yang diucapkan oleh orang yang telah menguasai bidang tersebut, dan diucapkan sewaktu duduk bersama untuk bermusyawarah menyetujui dan menyepakati suatu maksud pada pertemuan adat di alam Minangkabau (Jamin, 2006 : 5). Pidato adat tersebut berlangsung seperti orang yang sedang berdiskusi, atau orang yang berbalas pantun tepatnya. Pelaksanaan panitahan diwakili oleh dua orang pemuda yang sudah bergelar dari masing-masing pihak. Dalam menyampaikan panitahan tersebut sebelum memutuskan untuk menjawab pertanyaan lawan bicara, selalu meminta pendapat dari ninik mamak serta pihak yang berwenang untuk mendapatkan kata mufakat, sehingga apa yang diputuskan dalam suatu upacara adat berdasarkan hasil musyawarah dan mufakat. Budaya musyawarah seperti inilah yang terdapat pada masyarakat Nagari Paninjauan.

Orang Minangkabau cendrung tidak terus terang dalam mengungkapkan sesuatu yang tersimpan dalam pikirannya. Inilah penggalan kesimpulan penelitian Frederick K. Errington, seorang peneliti dari Amerika yang mempelajari Manner and Meaning in 
West Sumatera. Contohnya dalam hal meminta, jika seseorang membutuhkan atau menginginkan sesuatu, ia berusaha menghindari penggunaan ungkapan langsung. Meminta sesuatu dengan ungkapan langsung dianggap tidak sopan bahkan menjatuhkan harga diri (Oktavianus, 2012 : 5). Penelitian tersebut merupakan sumbangsih yang besar bagi Indonesia khususnya masyarakat Minang itu sendiri dalam mengenal dan memahami adat dan budayanya. Bahasa kiasan digunakan sebagai alternatif pada contoh tersebut untuk mengungkapkan permintaannya. Sebagaimana permintaan dari mamak kepada ninik mamak untuk menentukan gelar bagi marapulai, menggunakan bahasa kiasan tentunya. Itulah sebaik-baik bahasa untuk mengungkapkan keinginan dan permintaan terhadap suatu hal bagi masyarakat Minangkabau.

Upacara pernikahan dalam adat di Nagari Paninjauan memiliki ciri khas salah satunya terletak pada bahasa yang digunakan dalam upacara. Bahasa petatah petitih yang penuh makna (kiasan) yang indah dan sopan santun seperti diungkapkan dalam pepatah minang nan baiak iyolah budi, nan indah iyolah baso (yang baik adalah budi yang indah adalah bahasa) menjadikan pernikahan penuh kebahagiaan dan kelembutan. Bahasa petatah-petitih (panitahan) digunakan pada setiap pertemuan mamak antara kedua belah pihak pada proses upacara pernikahan. Bahasa kiasan terdapat pada panitahan yang disampaikan oleh mamak maupun ninik mamak dalam suatu upacara adat. Hasil wawancara dan observasi yang dilaksanakan pada bulan Desember-Januari 2015 di Nagari Paninjauan, peneliti memperoleh data tentang bahasa kiasan yang terdapat dalam panitahan pada upacara pernikahan manjapuik marapulai di Nagari Paninjauan.

Hasil wawancara yang dilakukan peneliti dengan para informan menemu- kan bahwa terdapat 27 kalimat dari 82 kalimat penggalan panitahan manjapuik marapulai yang mengandung kata kiasan. Kata kiasan tersebut mengandung makna dan terdapat simbol yang tersirat di dalamnya. Bahasa tersebut dianalisis secara historis dengan mencari informasi kepada para informan mengenai asal kata, alasan penggunaan kata kiasan tersebut dan hal-hal terkait yang mendukung penelitian. Bahasa yang telah dianalisis, kemudian di susun dengan menggunakan alat analisis pada penelitian ini, yakni analisis semiologi yang digagas Roland Barthes.

Hasil penelitian menemukan bahwa dari 27 kalimat terdapat kata kiasan yang digolongkan dalam tiga kategori yaitu :(1) terdapat 15 kalimat yang bersumber dari fenomena, aktivitas dan kejadian yang terdapat di alam, (2) terdapat 1 kalimat yang bersumber dari ajaran agama islam yang sesuai dengan falsafah Minang yaitu "adat basandi syarak, syarak basandi kitabullah" artinya adat yang bersendikan kepada agama islam (syarak), dan syarak bersendikan al-qur'an (kitabullah), (3) terdapat 11 kalimat yang bersumber dari hal-hal lain yaitu: etika masyarakat yang terdiri dari 6 kalimat, ideologi masyarakat Minang terdiri dari 2 kalimat, dan tradisi/ kebiasan masyarakat sebanyak 3 kalimat.

Kata kiasan yang bersumber dari fenomena, aktivitas dan kejadian yang terdapat di alam salah satu diantaranya adalah kata tantangan kato ayam lai barinduak (Tentang kata ayam yang mempunyai induk). Merupakan kalimat yang disampaikan oleh mamak (paman) pihak perempuan dalam memulai percakapan, yaitu diwakili oleh Katik Sampono. Terdapat penanda denotatif yaitu tentang kata ayam yang mempunyai induk, dan petandanya adalah konsep dari seekor anak ayam terlahir tentu jika ada induknya, itulah tanda denotatif dari kiasan tentang kata ayam yang 
mempunyai induk. Sedangkan pada tataran kedua, terdapat penanda konotatif yaitu anak ayam tersebut memerlukan ibunya yang akan menuntun hidupnya kelak, sedangkan petanda konotatifnya yaitu ayam yang ada induknya merupakan suatu isyarat dari Katik yang menghormati ninik mamak yang akan membimbing mereka yang muda-muda. Dengan kata lain, Katik berguru kepada orang yang dituakan dalam oleh adat dalam Nagari Paninjauan. Kata ayam tersebut digunakan orang Minang yang merupakan simbol yang terdapat pada alam. ayam merupakan salah satu makhluk hidup yang ada di alam ini dan ayam mempunyai induk merupakan fenomena yang terdapat di alam ini. Hal tersebut menunjukkan bahwa orang Minang berpedoman kepada apa yang terjadi di alam ini, dan memandangnya sebagai sesuatu yang perlu dipelajari. Begitulah masyarakat Minang mengkonstruksi bahasa yang terinspirasi dari alam, sebagai falsafah hidupnya.

Kalimat yang bersumber dari ajaran agama islam adat badiri di nan patuik, syarak mamakai pado dalil, limbago duduak bajauahan, tarapak sambah ka tangah, taunjuak ka muko rapek (adat berdiri pada yang patut, syarak memakai kepada dalil, aturan duduk berjauhan, terucap sembah ke tengah, ditujukan ke hadapan rapat). Merupakan ungkapan yang disampaikan Katik kepada Sutan Sati selaku mamak marapulai. Adat berdiri pada yang patut merupakan suatu ungkapan yang menyatakan bahwa apa yang telah diatur dan ditetapkan oleh adat merupakan suatu hal yang wajar (patut). Mengenai kata wajar seperti yang telah di jelaskan sebelumnya, Barthes berpendapat tentang kebudayaan yang menganggap suatu nilai sebagai hal yang "wajar" sebenarnya merupakan hasil proses konotasi: sejarah telah membuat konotasi berkembang menjadi mitos.
Barthes menanggap nilai-nilai budaya yang kita anut saat ini merupakan hasil konotasi, karena memiliki arti khusus dalam budaya tersebut. Seperti daun sirih, bagi kebanyakan orang hanya sekedar tumbuhan yang berfungsi sebagai obat bagi yang mengetahui kasiatnya, bagi yang tidak mengetahui akan memandang daun sirih sama dengan tumbuhan lainnya. Namun bagi masyarakat Minang, daun sirih merupakan daun keramat yang dipercayai melancarkan suatu acara sehingga selalu hadir dalam setiap upacara adat. Itulah yang dikatakan Barthes sebagai makna konotatif yang berkembang menjadi mitos.

Syarak memakai kepada dalil menunjukkan bahwa falsafah adat Minangkabau yaitu adat basandi syarak, syarak basandi kitabullah (adat bersendi syarak, syarak basandi Kitabullah/al-qur'an). Syarak adalah agama, adat orang Minang berpedoman kepada agama, yaitu agama islam, dan islam berlandaskan kepada Kitabullah yaitu al-qur'an. Syarak memakai pada dalil maksudnya adalah ajaran islam berpedoman kepada dalil, yaitu firman Allah SWT yang terdapat dalam al-qur'an dan Hadist Nabi. Aturan adat menyatakan dalam rapat atau acara dimana antara komunikator dengan lawan bicaranya (komunikan) duduk berjauhan, hendaknya mengucapkan sembah (salam) kepada sekalian orang yang hadir dalam acara tersebut. Budaya tersebut didasarkan pada ajaran syarak yang menyatakan bahwa adab dalam bertemu dengan seseorang hendaklah mengucapkan salam dan menyapa orang tersebut. Sembah yang dimaksud adat merupakan ucapan salam dan menyapa hadirin yang ada dalam acara sebagai bentuk penghargaan kepada setiap orang yang hadir.

Kata kiasan yang mengandung etika masyarakat terdapat pada kalimat kok buni lah samo tadanga, kok rupo lah samo taliek, tabik kabanaran dari si alek (Kalau 
bunyi sudah sama terdengar, kalau rupa sudah sama terlihat, muncul kebenaran dari pihak yang datang/si alek). Petanda denotatifnya adalah Suara yang sudah terdengar, bentuk yang sudah terlihat, merupakan kebenaran yang dikemukakan si alek (pihak yang datang). Kebenaran yang dimaksud adalah apa yang dikemukakan oleh Katik baik perkataan yang telah di dengar maupun benda adat yang terlihat oleh para hadirin yang telah sesuai dengan adat yang berlaku. Syarat untuk menyampaikan paham tersebut telah dipenuhi oleh Katik. Katik sudah diperbolehkan untuk menyampaikan pahamnya. Sebelum dipersilahkan menyampaikan paham tersebut, ada yang tidak boleh dilanggar dalam upacara ini yaitu musyawarah, yang sudah menjadi ideologi bagi masyarakat di Nagari Paninjauan ini. Demikianlah etika masyarakat di Nagari Paninjauan dalam menyampaikan suatu keinginan dari tamu (pihak perempuan) kepada tuan rumah (pihak pria). Harus melalui musyawarah terlebih dahulu dari pemuka adat, tamu baru boleh menyampaikan keinginannya datang ke rumah tersebut setelah ninik mamak (pemuka adat) sepakat untuk mengizinkannya.

Kalimat yang mengandung nilai ideologi masyarakat Minang adalah pusako duduak di nan rapek, kato surang dibulati, kato basamo dipaiyo, direnjeang kato jo mupakat (Pusaka duduk pada rapat, pendapat seseorang di dengarkan, pendapat orang banyak jadi keputusan, dibawa kata dengan mufakat). Pusaka maksudnya adalah aturan. Kata pusaka yang dipakai untuk melambangkan suatu aturan, karena aturan tersebut memang diwarisi secara turun temurun. Sudah dari dahulunya aturan dalam rapat dengan bermusyawarah untuk memperoleh suatu keputusan, yaitu dengan kata mufakat. Aturan itu terus diterapkan dari generasi ke generasi, maka dapatlah aturan tersebut dikatakan sebagai pusaka, yang diwarisi dari nenek moyang orang Minang. Budaya musyawarah di Minangkabau ini sudah ada sejak Indonesia masih dalam masa penjajahan seperti yang diungkapkan oleh pakar hukum Saptomo dalam bukunya yang berjudul Hukum dan Kearifan Lokal : Revitalisasi Hukum Adat Nusantara. Beliau mengungkapkan pada tahun 1900-an masyarakat minangkabau mempunyai lembaga kerapatan adat nagari, lembaga ini bekerja disemangati oleh budaya musyawarah mufakat. Dalam musyawarah tersebut, pihak yang berselisih dengan sukarela melunakkan sikap dan pendapatnya dan pada saat yang sama ia sekaligus menerima dan memahami pendapat pihak lain (Saptomo, 2009 : 106).

Pusaka mengharuskan setiap forum mendengarkan setiap pendapat yang disampaikan oleh seseorang. Pendapat orang banyak menjadi keputusan, setelah dimusyawarahkan tentunya. Pendapat bersama itulah yang disebut kata mufakat. Inilah nilai budaya yang dinyatakan sebagai mitos oleh Barthes, nilai yang mengandung ideologi didalamnya. Datuk menyampaikan kepada Katik perihal pusaka agar nilai budaya tersebut tidak lekang oleh panas, dan tidak lapuk karena hujan. Jadi selalu diterapkan pusaka ini di setiap upacara adat dan dalam keseharian. Pusaka merupakan aturan yang boleh dikatakan wajib ada dalam setiap upacara adat, bahkan dalam panitahan manjapuik marapulai saja sudah terdapat tiga kali musyawarah yang terjadi yaitu : (1) musyawarah yang dilakukan dengan meminta persetujuan dari ninik mamak pihak marapulai agar diizinkan menyampaikan suatu paham (maksud kedatangan) pihak perempuan, (2) musyawarah yang dilakukan oleh ninik mamak untuk memberi izin kepada pihak perempuan menjemput marapulai 
dan (3) musyawarah untuk memberi gelar kepada marapulai sebagai orang yang akan menjadi tamu terhormat di rumah istrinya, dalam hal ini ninik mamak yang hadir, tuan rumah dan orang yang berwenang saja yang melakukan musyawarah pemberian gelar tersebut.

Kalimat yang terdapat nilai tradisi/ kebiasan masyarakat terdapat pada kata kiasan berikut: di ketek nan banamo di gadang nan bagala (Saat kecil yang bernama saat besar yang bergelar). Kiasan tersebut merupakan tradisi masyarakat Minang dalam menghormati orang yang sudah dewasa. Dewasa bagi masyarakat Paninjauan adalah apabila orang tersebut sudah memiliki keluarga baru (beristri) dan memikul tanggaung jawab terhadap keluarga barunya. Gelar ini hanya diberikan kepada laki-laki karena ia merupakan kepala keluarga. Selain itu, laki-laki Minang yang sudah dewasa nantinya akan menjadi mamak bagi anak kakaknya (kemenakan). Mamak bertanggung jawab untuk mengurus kemenakannya disamping mengurus anakanaknya. Pepatah Minang menerangkan tentang tanggung jawab mamak kepada kemenakannya dalam ungkapan anak dipangku, kamanakan dibimbiang (anak dipangku, kemenakan dibimbing). laki-laki dewasa (marapulai) sebagai pendatang di lingkungan istrinya yang perannya tidak begitu kuat untuk mendominasi keluarga. Namun di rumah orang tuanya, peran lakilaki ini sangat besar. Dia nantinya yang akan melindungi harta pusaka dan mendidik serta membimbing kemenakannya. Itulah yang membuat laki-laki minang yang telah menikah akan diberikan gelar, agar kemenakan menghormatinya dan disegani masyarakat.

Umumnya simbol yang terdapat dalam kata kiasan menunjuk kepada alam. terlihat dari banyaknya jumlah kalimat yang mengandung kata kiasan yang terinspirasi dari alam daripada nilai-nilai budaya lainnya. hal tersebutsesuai dengan falsafah Minang yaitu "alam takambang manjadi guru" dimana masyarakat Minang dalam mengkonstruksi/menciptakan budayanya berdasarkan apa yang terdapat di alam. Aktivitas, fenomena, atau apapun yang terdapat di alam ini bisa dijadikan pelajaran. Hal tersebut mengisyaratkan bahwa orang Minang, khususnya masyarakat di Nagari Paninjauan hendaknya selalu belajar. Belajar tidak hanya dilakukan di bangku sekolah saja, namun dimana saja dengan memperhatikan fenomena dan peristiwa yang terdapat di alam. Banyak hal yang bisa dijadikan pelajaran sehingga manusia hendaknya selalu terus belajar.

Mengacu kepada gagasan Mulyana (2008 : 92) yang mengatakan bahwa lambang atau simbol merupakan salah satu kategori tanda, Littlejohn (dalam Sobur, 2004 : 15) juga berpendapat bahwa tanda merupakan basis dari seluruh komunikasi. Tanda menjadi dasar dalam berkomunikasi dan berinteraksi antara sesama manusia. Komunikasi yang terjadi baik secara verbal maupun nonverbal terdapat tanda di dalamnya. Komunikasi verbal yang terjadi antara mamak dari kedua belah pihak mempelai lewat panitahan juga terdapat tanda. Tanda tersebut yang ditelaah maknanya oleh peneliti, dalam menganalisis tanda pada panitahan tersebut peneliti menggunakan suatu ilmu atau metode analisis mengkaji tanda. Ilmu tersebut adalah "semiotika", dalam istilah Barthes yaitu "semiologi" yang telah dijabarkan dalam analisis data penelitian.

Sesuai dengan pendapat spradley (1997) bahwa simbol, baik secara verbal maupun nonverbal menunjuk kepada sesuatu. Simbol bahasa kiasan dalam panitahan manjapuik marapulai menunjuk kepada alam. Alam yang menjadi sumber inspirasi dan falsafah hidup orang Minang yaitu "alam 
takambang manjadi guru". Simbol merupakan kebutuhan bagi setiap manusia yang memiliki akal dan pikiran. Susanne Langer (dalam Mulyana, 2008:92) mempertegas dengan menyatakan bahwa simbol merupakan salah satu kebutuhan pokok manusia, kebutuhan simbolisasi atau penggunaan lambang inilah yang menjadi pembeda antara manusia dengan makhluk hidup lainnya. Komunikasi simbolik yang terdapat pada panitahan dalam acara manjapuik marapulai tersebut membuktikan bahwa manusia merupakan makhluk hidup yang berbeda dengan makhluk hidup lainnya. Manusia dengan akal pikirannya menciptakan dan mengkonstruksi simbol-simbol tersebut sesuai dengan budaya yang ada sehingga dapat dipahami oleh masyarakat yang ada dalam komunitasnya.

\section{Simpulan}

Ada beberapa hal yang menarik dari penelitian ini, yaitu: Pertama, simbol yang terdapat dalam bahasa kiasan pada panitahan manjapuik marapulai umumnya merupakan simbol menunjuk kepada alam, yaitu terdapat $15 \mathrm{kalimat}$ yang mengandung kata kiasan dengan simbol yang terdapat di alam. Satu (1) kalimat yang terdapat nilai agama di dalamnya, yaitu ajaran agama Islam yang menjadi agama masyarakat di Nagari Paninjauan. Selebihnya kalimat yang mengandung etika, ideologi dan tradisi masyarakat sebanyak sebelas (11) kalimat.

Kedua, makna yang terdapat dalam bahasa kiasan tersebut merujuk kepada alam. Hal ini sesuai dengan falsafah Minang yaitu "alam takambang manjadi guru" seperti yang terdapat pada kalimat Tantangan kato ayam lai barinduak, simbol dari ayam merupakan sesuatu yang terdapat di alam, dimana ayam membutuhkan induknya yang menuntun kehidupannya kelak, seperti generasi muda yang memerlukan ninik mamak yang menuntunnya dan memberi petunjuk mengenai adat istiadat Minang. Ketiga, makna yang mengandung nilai agama yaitu Adat badiri di nan patuik, syarak mamakai pado dalil, limbago duduak bajauahan, tarapak sambah ka tangah, taunjuak ka muko rapek. Ajaran agama yang terdapat dalam kalimat ini adalah mengucapkan salam kepada orang yang hadir pada acara manjapuik marapulai tersebut. Keempat, makna yang mengandung ideologi, etika serta tradisi masyarakat seperti pada kalimat Kok buni lah samo tadanga, kok rupo lah samo taliek, tabik kabanaran dari si alek, merupakan etika masyarakat di Nagari Paninjauan dalam menyampaikan suatu keinginan yaitu tidak menyampaikan secara langsung, namun dengan menggunakan kata kiasan yang tersirat pesan di dalamnya. Pesan tersebut juga dimengerti oleh komunitas, yaitu masyarakat Nagari Paninjauan.

Akhirnya penelitian ini diharapkan dapat menjadi referensi pada orang Minang agar tidak kehilangan jati diri sebagai orang Minang. Selain itu, penelitian yang berkaitan dengan komunikasi lintasbudaya ini menarik untuk dikaji dari etnis lainnya yang banyak variasinya di Indonesia yang multikultural.

\section{Daftar Pustaka}

Amir. (2003). Adat Minangkabau : Pola dan Tujuan Hidup Orang Minang. Jakarta: PT.Mutiara Sumber Widya.

Bungin, Burhan. (2008). Sosiologi Komunikasi : Teori, Paradigma dan Diskursus Teknologi Komunikasi di Masyarakat, Jakarta: Kencana Prenada Media Group.

Hoed, Benny H. (2011). Semiotik dan Dinamika Sosial Budaya. Jakarta: Komunitas Bambu.

Jamin, Jamilus. (2006). Alur Panitahan Adat Minangkabau. Bukittinggi: Kristal Multimedia. 
Mulyana, Deddy. (2008). Ilmu Komunikasi : Suatu Pengantar. Bandung: PT.Remaja Rosdakarya.

Oktavianus. (2012). Bertutur Berkias dalam Bahasa Minangkabau. Padang: Fakultas Ilmu Budaya Universitas Andalas.

Saptomo, Ade. (2009). Hukum dan Kearifan Lokal : Revitalisasi Hukum Adat Nusantara. Jakarta: Grasindo.

Sayuti, M. (2005). Tau Jo Nan Ampek (Pengetahuan yang Empat Menurut Ajaran Budaya Alam Minangkabau). Padang: Mega Sari.

Sobur, Alex. (2004). Semiotika Komunikasi. Bandung: PT. Remaja Rosdakarya.

Tinarbuko, Sumbo. (2010). Semiotika Komunikasi Visual. Yogyakatra: Jalasutra.
Wibowo, Indiwan Seto Wahyu. (2011). Semiotika Komunikasi: Aplikasi Praktis bagi Penelitian dan Skripsi Komunikasi. Jakarta: Mitra Wacana Media.

Zulkarnaini. (2003). Minangkabau Ranah nan Den Cinto : Budaya Alam Minangkabau, Buku Pelajaran untuk Sekolah Dasar Kelas 5. Bukittinggi: Usaha Ikhlas.

\section{Internet}

(http://kbbi.web.id/kias), diakses tanggal 22 September 2014, pukul 13.00 WIB.

(http:/ / Katakiasan-WikipediabahasaIn donesia,ensiklopediabebas.html), diakses tanggal 22 September 2014, pukul 13.00 WIB.

(http://id.m.wikipedia.org/wiki/ pernikahan), diakses tanggal 18 november 2014, pukul 14.20 WIB. 